\title{
Adolescent pregnancy trends in the last decade
}

\author{
(iD) Denise Leite Maia Monteiro ${ }^{\mathbf{1 , 2}}$ \\ José Augusto Ferraz dos Santos Martins ${ }^{2}$ \\ (iD) Nádia Cristina Pinheiro Rodrigues ${ }^{1,3}$ \\ (iD) Fátima Regina Dias de Miranda ${ }^{1,4}$ \\ (DD/sabel Maria Santos Lacerda ${ }^{1}$ \\ (iD) Flávio Monteiro de Souza ${ }^{1}$ \\ (iD) Ana Clara Tavares Wong ${ }^{5}$ \\ (iD) Roberta Monteiro Raupp ${ }^{6}$ \\ DAlexandre José Baptista Trajano ${ }^{1,4}$

\begin{abstract}
1. Universidade do Estado do Rio de Janeiro (Ueri) - Rio de Janeiro, RJ, Brasil. 2. Centro Universitário Serra dos Órgãos (Unifeso) - Teresópolis, RJ, Brasil. 3. Escola Nacional de Saúde Pública, Fundação Oswaldo Cruz (Fiocruz) - Rio de Janeiro, RJ, Brasil. 4. Universidade do Grande Rio (Unigranrio) - Rio de Janeiro, RI, Brasil 5. Instituto de Aplicação Fernando Rodrigues da Silveira (CAp-Uerj) - Rio de Janeiro, RJ, Brasil. 6. Instituto de Comunicação e Informação Científica e Tecnológica em Saúde (ICICT), Fundação Oswaldo Cruz (Fiocruz) - Rio de Janeiro (RJ), Brasil.
\end{abstract}

http://dx.doi.org/10.1590/1806-9282.65.9.1209

\section{SUMMARY}

INTRODUCTION: Teenage pregnancy is a universal phenomenon, with higher prevalence in developing countries. Although there has been a reduction in Brasil since the year 2000, the age-specific fertility rate for this age group remains high.

OBJECTIVE: To evaluate the frequency of adolescence pregnancy in in Brasil from 2006 to 2015 and its association with the Human Development Index (HDI).

METHODS: A descriptive epidemiological study, conducted by searching the database of the Department of Informatics of the Unified Health System (DATASUS), using information from the Information System on Live Births (SINASC) for the five Brazilian regions.

RESULTS: There was a reduction in the percentage of live births (LB) from adolescent mothers (10 to 19 years old) in Brasil by $13.0 \%$ over the last ten years. This decline was observed in all Brazilian regions among mothers aged 15 to 19 years. The number of $L B$ increased by 5.0\% among mothers aged 10 to 14 years in the North and decreased in the other regions, with higher rates in the South (18.0\%). The specific fertility rate for the 15-19-year-old group decreased from 70.9/1,000 to 61.8/1,000 in the period. The proportion of LB is inversely associated with the HDI, except in the Northeast (the lowest HDI in the country), where there was a significant reduction (18.0\%) among mothers aged $15-19$ and $2 \%$ among those aged $10-14$ years.

CONCLUSION: Teenage pregnancy in Brasil is in slow decline, especially among mothers aged 10-14 years and is inversely associated with the HDI, except in the Northeast.

KEYWORDS: Pregnancy in Adolescence. Prevalence. Epidemiology. Adolescent.

\section{INTRODUCTION}

Worldwide, approximately 16 million girls aged between 15 and 19 years and 2 million girls younger than 15 years have children each year, with a higher frequency of live births (LB) from adolescent moth- ers in developing countries. Over half of the women in Africa and around one third in Latin America and the Caribbean will give birth before they are 20 years old. ${ }^{1.2}$ In Brasil, approximately one in every five Brazilian women has their first child before the age of 
20 , a proportion that has remained the same in the past ten years, despite the drop in the percentage of LB from adolescent mothers between 2000-2011. This reduction was noticed in all Brazilian regions for women aged between 15 and 19 years, but numbers increased in the North and Northeast region for ages between 10-14 years. ${ }^{3}$

According to the 2018 Report of the Pan American Health Organization/World Health Organization (PAHO/WHO), the United Nations Children's Fund (Unicef) and the United Nations Population Fund (UNFPA), the global rate of teenage pregnancy remains high, estimated at 46 births per 1,000 girls, while in Latin America and the Caribbean the rate remains the second-highest in the world, estimated at 66.5 births/1,000 women aged between 15 and 19 years, behind only Sub-Saharan Africa. The Brazilian rate is estimated at 68.4 births/1,000 adolescents. ${ }^{4}$

Poverty and low formal education levels, which are intrinsically intertwined, constitute the backdrop for of the countries where early pregnancy rates remain high, unlike what is observed in most developed countries..$^{4.5}$ Therefore, this should be treated as a public health problem, especially since it affects populations of developing countries. However, in certain cases, this may be the result of a decision by the teenager or of their own local culture, especially in countries of South Asia and Sub-Saharan regions. ${ }^{5}$

The objective of this paper is to determine the frequency of adolescence pregnancy in both age groups (10-14 and 15-19 years), in all five regions of Brasil, and investigate its association with the Human Development Index (HDI) of each region.

\section{METHODS}

This is a descriptive study based on data from the Information System on Live Births (SINASC) of the Single Health System Department of Informatics (DATASUS), a system managed by the Secretariat of Health Surveillance, along with state and municipal health secretariats. These institutions collect the Declarations of Live Births (DLB) from health services and notary offices (for home births) and input the data into the SINASC. ${ }^{6}$

The completion of a DLB is mandatory for the civil registry of a newborn. To prepare this study, we used the following variables: birth according to the place of residence of the mother, birth according to the region of Brasil, year of birth, and mother's age. ${ }^{6}$
The study included all women who had an LB in the years 2006 to 2015 in Brasil. We sought data on the total number of LB per region, as well as in the age ranges of 10-14 and 15-19 years, to calculate the percentage of LB from adolescent mothers. We excluded from the total of LB those whose mother's age was not reported (1,048 LB between 2006-2011 and 282 LB between 2012-2015). We also analyzed the association between the frequency of adolescence pregnancy and the Human Development Index (HDI) of each region, which is a summarized measurement of progress in the long term, using three basic dimensions: income, education, and health. ${ }^{7}$

Since the census by the Brazilian Institute of Geography and Statistics (IBGE) provides the HDI per state/municipality, we calculated the average HDI of each state weighted by the population to obtain the HDI of each region. We used as a reference the HDI of the IBGE census (2010) because it is the most recent data available. ${ }^{8}$ Relative and absolute frequencies of the number of LB according to the mother's age and year of occurrence were calculated. Increases or reductions in the percentages from 2006-2015 were calculated using the formula:

[(\% of LB from 2015 - \% of LB from 2006) / \% of LB from 2006] $x 100$

The age-specific fertility rate (ASFR) represents the average number of children born alive a woman of a specific age and of a specific area has had in the year considered. ${ }^{9}$ The rate may be presented per group of 1,000 women for each age group. The ASFR was calculated by dividing the total number of LB from mothers aged between 10-14 years and 15-19 years by the total resident population of adolescents of this age, multiplied by $1000 .^{9.10}$

Since the database used is of public domain, it was not necessary to submit the project for approval by our institution's Research Ethics Committee.

\section{RESULTS}

The percentage of LB from adolescents between 2006-2010 increased from $21.5 \%$ to $19.3 \%$ (a reduction of 12.7\%), with a slight increment between 2010-2014 (an increase of 1.8\%) and a drop in 2015 (a reduction of 2.7\%). Considering the period studied, there was a decrease from $21.5 \%$ (2006) to $18.1 \%$ (2015), driven by the proportion of mothers aged between 15 and 19 years. The reduction of births among adolescent mothers in Brasil totaled $13.5 \%$ in ten years (Table 1). The ASFR 
TABLE 1. DISTRIBUTION OF LIVE BIRTHS (LB) ACCORDING TO THE MOTHER'S AGE AND PERCENTAGE VARIATION IN THE RATE OF ADOLESCENT PREGNANCY (AP) FROM 2006 TO 2015.

\begin{tabular}{l|l|l|l|l|l} 
Year & $\begin{array}{l}10 \text { to } 14 \\
\text { years }\end{array}$ & 15 to 19 years & $\begin{array}{l}\text { Total of LB from } \\
\text { adolescents }\end{array}$ & Total of LB & Freq \% AP \\
\hline 2006 & 27,610 & 605,270 & 632,880 & $2,944,928$ & 21.5 \\
\hline 2007 & 27,963 & 582,409 & 610,372 & $2,891,328$ & 21.1 \\
\hline 2008 & 28,678 & 570,560 & 599,238 & $2,934,828$ & 20.4 \\
\hline 2009 & 27,807 & 546,959 & 574,766 & $2,881,581$ & 19.9 \\
\hline 2010 & 27,049 & 525,581 & 552,630 & $2,861,868$ & 19.3 \\
\hline 2011 & 27,785 & 533,103 & 560,888 & $2,913,160$ & 19.3 \\
\hline 2012 & 28,236 & 531,909 & 560,145 & $2,905,789$ & 19.3 \\
\hline 2013 & 27,989 & 532,002 & 559,991 & $2,904,027$ & 19.3 \\
\hline 2014 & 28,244 & 534,364 & 562,608 & $2,979,259$ & 18.9 \\
\hline 2015 & 26,700 & 520,864 & 547,564 & $3,017,668$ & 18.1 \\
\hline Total & 278,061 & $5,483,021$ & $5,761,082$ & $29,234,436$ & \\
\hline
\end{tabular}

Source: MS/SVS/Dasis - Information System on Live Births - SINASC.

TABLE 2. AGE-SPECIFIC FERTILITY RATE PER AGE GROUP (10-14 AND 15-19 YEARS) TOTAL LB FROM MOTHERS AGED BETWEEN 10-14 YEARS AND 15-19 YEARS/TOTAL POPULATION RESIDENT ADOLESCENTS, FROM THESE GROUPS, MULTIPLIED BY 1,000.

\begin{tabular}{|c|c|c|c|c|c|c|}
\hline Year & $\begin{array}{l}10 \text { to } 14 \\
\text { years }\end{array}$ & $\begin{array}{l}\text { Adolescent } \\
\text { population }\end{array}$ & $\begin{array}{l}\text { ASFR/1,000 } \\
\text { adol }\end{array}$ & $\begin{array}{l}15 \text { to } 19 \\
\text { years }\end{array}$ & $\begin{array}{l}\text { Adolescent } \\
\text { population }\end{array}$ & $\begin{array}{l}\text { ASFR/1,000 } \\
\text { adol }\end{array}$ \\
\hline 2006 & 27,610 & $8,462,615$ & 3.26 & 605,270 & $8,537,516$ & 70.90 \\
\hline 2007 & 27,963 & $8,455,516$ & 3.31 & 582,409 & $8,501,358$ & 68.51 \\
\hline 2008 & 28,678 & $8,451,680$ & 3.39 & 570,560 & $8,482,441$ & 67.26 \\
\hline 2009 & 27,807 & $8,449,676$ & 3.29 & 546,959 & $8,469,621$ & 64.58 \\
\hline 2010 & 27,049 & $8,444,955$ & 3.20 & 525,581 & $8,456,048$ & 62.15 \\
\hline 2011 & 27,785 & $8,453,733$ & 3.29 & 533,103 & $8,445,364$ & 63.12 \\
\hline 2012 & 28,236 & $8,441,389$ & 3.34 & 531,909 & $8,438,804$ & 63.03 \\
\hline 2013 & 27,989 & $8,407,297$ & 3.33 & 532,002 & $8,435,542$ & 63.07 \\
\hline 2014 & 28,244 & $8,351,178$ & 3.38 & 534,364 & $8,434,160$ & 63.36 \\
\hline 2015 & 26,700 & $8,276,054$ & 3.23 & 520,864 & $8,430,077$ & 61.79 \\
\hline Total & 278,061 & $84,194,093$ & 3.30 & $5,483,021$ & $84,630,931$ & 64.79 \\
\hline
\end{tabular}

Source: IBGE/Directorate of Research. Coordination of Population and Social Indicators. Management of Studies and Analyses of Demographic Dynamics. Projection of the population of Brasil and Federated Units per age and gender for 2000-2030.

for the age group between 15-19 years had a reduction from 70.9/1,000 in 2006 to $61.8 \%$ in 2015 (Table 2). The reduction in the number of LB from mothers aged between $15-19$ years was $14.0 \%$, while among those aged between $10-14$ years, it was only $3 \%$ (Table 3 ).

After analyzing the regions of the country separately regarding these ten years, we found that the number of LB from mothers aged between 10 and 14 years increased in the Northern Region (5.0\%), while in other Brazilian regions, it decreased $(2.0 \%$ in the Northeast; $8.0 \%$ in the Central-West; $3.0 \%$ in the Southeast; and $18.0 \%$ in the South). The number of LB among mothers aged between 15-19 years decreased in all Brazilian regions (9.0\% in the North; $18.0 \%$ in the Northeast; $11.0 \%$ in the Central-West; $12.0 \%$ in the Southeast, and $14.0 \%$ in the South) (Table 3).

After analyzing the last HDI record available, we found that the regions that have the highest HDI are the Southeast, South, and Central-West, with HDIs between 0.75 to 0.76 , while the North and Northeast have HDIs between 0.65 and 0.66 . The regions that have the highest HDI in the country were the ones with the lowest percentage of LB from adolescent mothers, while the regions with the lowest HDI had the highest percentages of LB from adolescent mothers. The Northeast had the lowest percentage of reduc- 
TABLE 3. DISTRIBUTION OF LIVE BIRTHS ACCORDING TO THE MOTHER'S AGE AND PERCENTAGE VARIATION IN THE RATE OF ADOLESCENT PREGNANCY (AP) FROM 2006 TO 2015.

\begin{tabular}{|c|c|c|c|c|c|c|c|c|c|}
\hline $\begin{array}{l}\text { Age of } \\
\text { mother }\end{array}$ & Region & 2006 & 2010 & 2014 & 2015 & $\begin{array}{l}\text { Variation } \\
2006-2010\end{array}$ & $\begin{array}{l}\text { Variation } \\
2010-2014\end{array}$ & $\begin{array}{l}\text { Variation } \\
2014-2015\end{array}$ & 10 years \\
\hline \multirow{6}{*}{$\begin{array}{l}10 \text { to } 14 \\
\text { years }\end{array}$} & Southeast & 7,288 & 7,028 & 7,700 & 7,081 & $-4 \%$ & $10 \%$ & $-8 \%$ & $-3 \%$ \\
\hline & Central-West & 2,232 & 2,100 & 2,311 & 2,050 & $-6 \%$ & $10 \%$ & $-11 \%$ & $-8 \%$ \\
\hline & Northeast & 10,287 & 10,292 & 10,176 & 10,064 & 0 & $-1 \%$ & $-1 \%$ & $-2 \%$ \\
\hline & Norte & 4,773 & 4,864 & 5,190 & 5,014 & $2 \%$ & $7 \%$ & $-3 \%$ & $5 \%$ \\
\hline & South & 3,030 & 2,765 & 2,867 & 2,491 & $-9 \%$ & $4 \%$ & $-13 \%$ & $-18 \%$ \\
\hline & Brasil & 27,610 & 27049 & 28244 & 26,700 & $-2 \%$ & $4 \%$ & $-5 \%$ & $-3 \%$ \\
\hline \multirow{6}{*}{$\begin{array}{l}15 \text { to } 19 \\
\text { years }\end{array}$} & Southeast & 196,111 & 172,266 & 177,945 & 172,251 & $-12 \%$ & $3 \%$ & $-3 \%$ & $-12 \%$ \\
\hline & Central-West & 46,284 & 40,525 & 43,185 & 41,319 & $-12 \%$ & $7 \%$ & $-4 \%$ & $-11 \%$ \\
\hline & Northeast & 208,291 & 174,929 & 171,784 & 170,122 & $-16 \%$ & $-2 \%$ & $-1 \%$ & $-18 \%$ \\
\hline & Norte & 84,474 & 75,829 & 79,190 & 77,098 & $-10 \%$ & $4 \%$ & $-3 \%$ & $-9 \%$ \\
\hline & South & 70,110 & 62,032 & 62,260 & 60,074 & $-12 \%$ & 0 & $-4 \%$ & $-14 \%$ \\
\hline & Brasil & 605,270 & 525,581 & 534,364 & 520,864 & $-13.2 \%$ & $1.7 \%$ & $-2.5 \%$ & $-14 \%$ \\
\hline \multicolumn{2}{|c|}{ Total Brasil(10-19 years) } & 632,880 & 552,630 & 562,608 & 547,564 & $-12.7 \%$ & $1.8 \%$ & $-2.7 \%$ & $-13.5 \%$ \\
\hline
\end{tabular}

tion in the age group between 10-14 years, while in the North there was an increase in the percentage of LB from adolescents aged between 10-14 years (Figure 1).

\section{DISCUSSION}

The present study shows a tendency of reduction of teenage pregnancy over the decade studied. Its prevalence decreased between 2006-2010 and remained stable until 2014. A new reduction in 2015 may have been driven by the expansion of the Family Health Program and tan increased access to contraceptive methods. ${ }^{11}$ Another explanation may be related to the country's demographic transition, with the reduction of the adolescent population and increase of the population over 60 years old or older. ${ }^{12}$

The study found a decrease of LB from adolescent mothers in Brasil caused by a reduction in the number of LB from mothers aged between 15 and 19 years old. However, it also found a slight increase in births in the age group younger than 15 years old, over the period studied.

According to the IBGE, Brasil had a sharp drop in the total number of live births between 2000-2001, 2005-2006, 2008-2009, and 2015-2016. Between 2009 and 2013, births remained at the same level, with an increase of $2.5 \%$ and $1.5 \%$, on average, in 2014 and 2015, respectively. The behavior of the total number of LB followed a reduction trend similar to that of the group of adolescent mothers, except in 2015. The North and Northeast had the greatest drop in the Total Fertility Rate (TFR) between 2000-2015. The drop was caused by the reduction of the TEF among women aged between 15-29 years old. It is estimated that the average TFR of the Northern region reached, in 2015, 2.1 children per woman, which corresponds to the limit that ensures the population replacement level. This same figure was reached in the Northeast in 2004, and at the beginning of the 2000s in other regions. In the Northeast, there was aging in the fertility pattern because, in recent years, it has become evident the increased participation in fertility by women aged 30-34 years and a reduction by the age group between $15-24$ years in the total fecundity. The Southeast and South regions had fewer variations in the TFR, with slight drops or increases over the period, characterizing a postponement of pregnancy from 15-24 years to 30-39 years. ${ }^{10}$

Although the Brazilian TFR is already low, teenage pregnancy is still quite high. In Brasil, in 2015, the TFR was 1.72 children per woman, placing the country at the 158th position among countries with the highest fertility rate. ${ }^{9}$ In the United States of America (USA), in 2015, the fertility rate was 62.5/1,000 women aged between 15 and 44 years, and the TFR was 1.84 births $/ 1,000$ women. ${ }^{2.4}$

This study shows that, in Brasil, in 2015, there were 547,564 LB from adolescent mothers. In the US, in the same year, the overall rate of LB reached a historic low of 22.3 births for every 1,000 adolescents aged between 15-19 years old, a reduction of more than 60\% since 1991, totaling 229,715 LB from adoles- 


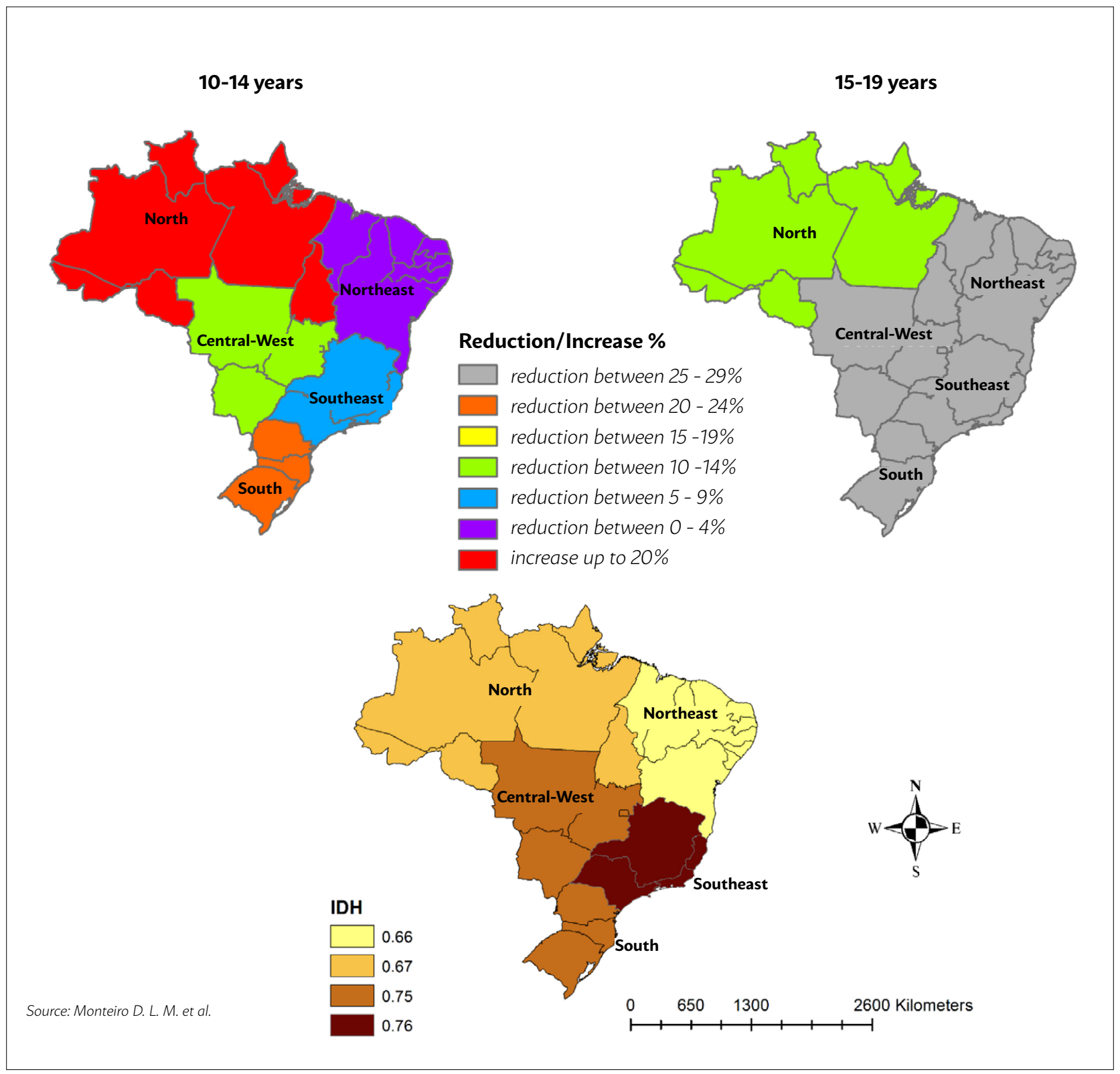

cent mothers. ${ }^{2.4}$ According to the WHO, in Brasil, that figure is 68.4/1,000 adolescents aged between 15-19 years old, higher than the Latin American average. Venezuela occupies the first position, with 80.9/1,000, followed by Ecuador with 77.3/1,000, Bolivia with 72.6/1,000, and then the United States. ${ }^{4.13}$ France has the lowest rates, with seven pregnancies per thousand teenagers. ${ }^{4}$ The results of this study indicate that, in Brasil, the ASFR for the age group between 15-19 years old dropped to $61.8 / 1,000$ teenagers in 2015 . The global rate of births among adolescents decreased from 65 births per 1,000 in 1990 to 47 in $2015 .{ }^{14}$ In Brasil, it remains high even with the reduction of births among adolescents aged between 15 and 19 years. What is most worrying is the stabilization tendency among the age group between 10-14 years old. ${ }^{3.6}$

The data presented represent only the total number of births among adolescent mothers, not the totality of teenage pregnancy cases, since it is not possible to quantify the number of abortions and stillbirths, which is a limitation of the study. Another limitation was the proportion of mothers whose age was not recorded because it could include adolescents. Therefore, the data may be underestimated and might not reflect the actual frequency of teenage pregnancy in Brasil. However, the reduction in the number of mothers whose age was not reported indicates an improvement in the quality of data collection by SINASC. ${ }^{12}$

Despite the reduction in fertility rates in Latin America and the Caribbean in recent years, among ad- 
olescents, that drop has been minimal over the last 30 years, and a tendency of increase has remained among women younger than 15 years old. West Africa has the highest rate of teenage pregnancy in the world, with a birth rate of 115 births per 1,000 adolescents. ${ }^{1.15}$

In Brasil, over the past ten years, the fertility of adolescents aged between 15 and 19 years dropped about $18.6 \%{ }^{16}$ Nevertheless, the participation of this group in total fertility remained high ${ }^{16}$. In Rio Grande do Sul, in 1999 , the fertility rate was $20.2 \%$ and $17.4 \%$ in 2008, with a reduction of 50 thousand births over this period. ${ }^{17}$ However, this is not the reality of the entire country, considering the results of this study in relation to mothers aged between 10-14 years.

A previous study by our research group has confirmed the decrease in the percentage of live births from mothers aged between 10-19 years old in Brasil, from $23.5 \%$ in 2000 to $19.3 \%$ in 2011 , and the reduction of the number of mothers whose aged is ignored, especially after 2005 . The reduction in the number of LB was observed in all Brazilian macroregions among mothers aged between 15-19 years old, but there was an increase among mothers younger than 15 years old in the North and Northeast regions (12.5\% and $13.4 \%$, respectively). ${ }^{3}$ The present study shows that in the North, the situation is now changing since there was a slight reduction in the rate of births from younger mothers. This is the first study to show this important result. The literature, when describing data on teenage pregnancy, most often refers to the age range between 15-19 years old. The relationship between adolescence pregnancy and social, educational, economic, and cultural factors indicate a decision to postpone the age of the pregnancy. Income inequality, underemployment, and low levels of formal education contribute to the increase in its incidence. ${ }^{18}$ This study confirms that Brazilian regions with higher HDI (South, Southeast, and Central-West) have lower rates of LB from adolescent mothers, which could be considered as a possible marker of development. ${ }^{3}$ The exception was the Northeast, where births from women aged 15-19 years had a greater reduction than expected since this is the region with the lowest HDI. Duarte et al. ${ }^{18}$ compared adolescents who lived in four areas with different degrees of social exclusion in Santo André (SP). Formal education had a statistically significant relationship with poorer areas, which accounted for a higher number of adolescents with less schooling. In addition, $76.8 \%$ of babies with low birth weight and a higher rate of fertility were found in poorer areas of the city. ${ }^{18}$

Pregnancy can take different meanings from the teenager's perspective. Therefore, it is important to emphasize that intentional pregnancy at a young age can be seen as a life project by the adolescent. Pregnancy at a young age may represent a search for autonomy and responsibility, as well as a source of satisfaction and a new identity with the role of a mother. Pregnancy can be seen as a way to mark their space in the family and be acknowledged by friends and family. ${ }^{19}$ When there is support by the family and partner, proper prenatal care, and continuation of the studies, a planned pregnancy at a young age can be a positive event.

Thus, although the statistics show a slight decline in their frequency, it is important to highlight the strategies for addressing the problem, so that the adolescence pregnancy can be a decision and not the consequence of the lack of public policies targeted at adolescents.

\section{RESUMO}

INTRODUÇÃO: A gravidez na adolescência é fenômeno universal, com maior prevalência nos países em desenvolvimento. Embora venha apresentando redução desde 2000 no Brasil, a taxa de fecundidade específica para essa faixa etária permanece elevada.

OBJETIVO: Avaliar a frequência da gravidez na adolescência no Brasil, no período de 2006 a 2015 , e a associação com o Índice de Desenvolvimento Humano (IDH).

MÉTODO: Estudo epidemiológico, descritivo, realizado por busca no banco de dados no Departamento de Informática do Sistema Único de Saúde (Datasus), utilizando informações do Sistema de Informação sobre Nascidos Vivos (Sinasc) sobre as cinco regiões brasileiras. RESULTADOS: Ocorreu queda do percentual de nascidos vivos (NV) de mães adolescentes (10 a 19 anos) no Brasil de $13,5 \%$ nos últimos dez anos. Essa redução foi notada em todas as regiões brasileiras, entre mães de 15 e 19 anos. O número de NV aumentou 5,0\% entre aquelas de 10 a 14 anos na Região Norte e foi reduzido nas demais regiões, sendo maior no Sul (18,0\%). A taxa de fecundidade específica de 15-19 anos diminiu de 70,9/1.000 para 61,8/1.000 no período. A proporção de NV se associa inversamente ao IDH, exceto no Nordeste, onde ocorreu importante redução (18,0\%) entre as mães de 15-19 anos e de 2\% entre 10-14 anos.

CONCLUSÃo: A gravidez na adolescência no Brasil encontra-se em lento declínio, especialmente entre 10-14 anos, e está inversamente associada ao IDH, exceto no Nordeste.

PALAVRAS-Chave: Gravidez na adolescência. Prevalência. Epidemiologia. Adolescente. 


\section{REFERENCES}

1. World Health Organization (WHO). Adolescent pregnancy. [cited 2018 Feb 23]. Available from: https://www.who.int/news-room/fact-sheets/detail/ adolescent-pregnancy

2. Martin |A, Hamilton BE, Ventura S|, Osterman MJK, Kirmeyer S, Mathews T], et al. Births: final data for 2015. Nat Vital Stat Rep. 2017;66(1):1. [cited 2018 May 30]. Available from: https://www.cdc.gov/nchs/data/nvsr/ nvsr66/nvsr66_01.pdf

3. Vaz RF, Monteiro DLM, Rodrigues NCP. Tendências da gravidez na adolescência no Brasil, 2000-2011. Rev Assoc Med Bras. 2016;62(4):330-5.

4. ONUBR Nações Unidas no Brasil. Taxa de gravidez adolescente no Brasil está acima da média latino-americana e caribenha. [cited 2018 Ago 11] Available from: https://nacoesunidas.org/taxa-de-gravidez-adolescente-no-brasil-esta-acima-da-media-latino-americana-e-caribenha/

5. Pinto e Silva |L, Surita FGC. Gravidez na adolescência: situação atual. Rev Bras Ginecol Obstet. 2012;34(8):347-50.

6. Ministério da Saúde. Departamento de Informática do SUS (DATASUS). Informações de Saúde (Tabnet) - Estatísticas vitais. [cited 2018 Mar 20]. Available from: http://www2.datasus.gov.br/DATASUS/index. php?area $=0205 \& i d=6936$

7. Programa das Nações Unidas para o Desenvolvimento (PNUD). PNUD Brasil. Desenvolvimento humano e IDH. [cited 2018 Nov 21]. Available from: http://www.br.undp.org/content/brazil/pt/home/idh0.html

8. Instituto Brasileiro de Geografia e Estatística (IBGE). Censo demográfico 2010. [cited 2018 Nov 21]. Available from: https://ww2.ibge.gov.br/home/ estatistica/populacao/ censo2010/

9. Instituto Brasileiro de Geografia e Estatística (IBGE). Brasil em síntese. [cited 2018 Dec 10]. Available from: https://brasilemsintese.ibge.gov.br/ populacao/taxas-de-fecundidade-total.html

10. Instituto Brasileiro de Geografia e Estatística (IBGE). Projeções da população. Brasil e Unidades da Federação. Revisão 2018. 2a. ed. [cited 2019 Apr 20]. Available from: https://loja.ibge.gov.br/projecoes-da-populac-o-brasile-unidades-da-federac-o-revis-o-2018.htm
11. Ministério da Saúde. Portal Brasil. [cited 2018 Dez 18]. Available from: http://www.brasil.gov.br/noticias/saude/2017/05/ numero-de-adolescentes-gravidas-cai-17-no-brasil

12. Vasconcelos $A M N$, Gomes MMF. Transição demográfica: a experiência brasileira. Epidemiol Serv Saúde. 2012;21(4):539-48.

13. Pan American Health Organization (PAHO), World Health Organization (WHO), United Nations Population Fund (UNFPA), United Nations Children's Fund (UNICEF). Accelerating progress toward the reduction of adolescent pregnancy in Latin America and the Caribbean. In: Washington, D.C., USA, 2016. [cited 2018 Sep 20]. Available from: http://iris. paho.org/xmlui/ bitstream/handle/123456789/34493/9789275119761eng. pdf? sequence $=1 \&$ is Allowed $=y \& u a=1$

14. UN DESA, Population Division. World population prospects: the 2017 revision, DVD edition. New York: UN DESA; 2017.UNDESA, Population Division. World population prospects, the 2015 revision (DVD edition) New York: UNDESA, Population Division; 2015.

15. UNFPA. Maternidade precoce: enfrentando o desafio da gravidez na adolescência UNFPA: situação da população mundial; 2013. [cited 2018 Sep 23]. Available from: http://www.unfpa. org.br/Arquivos/swop2013.pdf

16. Instituto Brasileiro de Geografia e Estatística (IBGE). Síntese de indicadores sociais, 2015. [cited 2018 Nov 23]. Available from: https://ww2.ibge.gov. $\mathrm{br} /$ home/estatistica/populacao/ condicaodevida/indicadoresminimos/ sinteseindicsociais2015/default.shtm

17. Cesar JA, Mendoza-Sassi RA, Gonzalez-Chica DA, Mano PS, Goulart-Filha SM. Características sociodemográficas e de assistência à gestação e ao parto no extremo sul do Brasil. Cad Saúde Pública. 2011;27(5):985-94

18. Duarte CM, Nascimento VB, Akerman M. Gravidez na adolescência e exclusão social: análise de disparidades intra-urbanas. Rev Panam Salud Publica. 2006;19(4):236-43.

19. Santos BR, Magalhães DR, Mora GG, Cunha A. Gravidez na adolescência no Brasil: vozes de meninas e de especialistas. Brasília: Instituto dos Direitos da Criança e do Adolescente (INDICA); 2017. [cited 2019 Jan 15]. Available from: http://unfpa.org.br/Arquivos/br_gravidez_adolescencia_2017.pdf. 